United States would demonstrate confidence in international adjudication and therefore could be viewed as a political asset, ${ }^{84}$ even if its challenges to the validity of the acts were not endorsed by the Court or had no significant effect upon the practice of the Organization. The broad majority of members of the United Nations, however, share the opinion of Judge Hudson that "no great international instrument could be completely selfexplanatory, and meaning should be given to its provisions, not so much by the rulings of judges on the bench of the Court, as by the experience of those who have the responsibility of making the instrument work." ${ }^{35}$

It is probable that those states might see in the readiness of the United States to leave with the Court the final determination of the legality of any interpretation or application of the Charter a direct and unwarranted challenge to a legal philosophy which they are not yet prepared to abandon. Therefore, it should not be surprising that, instead of invigorating the policy of the United States in the United Nations, the sudden acceptance of the compulsory jurisdiction of the Court in all cases concerning the interpretation or application of the Charter might contribute to its political isolation in the Organization.

Dan Ciobanu

The Fletcher School of

Law \& Diplomacy

\title{
CORRESPONDENCE
}

\section{TO THE EDITOR-IN-CHIEF}

I have read with great interest Mr. Rubin's comments on sunken submarines, in the October 1975 issue of the American Journal of International Law. ${ }^{1}$

I do not see however why we should follow American law or any law, other than natural law with respect to the ownership of things found floating or submerged in the ocean, or why the law should be different from

${ }^{34}$ As Professor Bin Cheng put it in another context:

[W] hen a State accepts in advance the duty to submit to international adjudication ... it must always behave in such a manner that, if brought before the court, its conduct stands at least a fair chance of being upheld. In other words, where a State has accepted in advance the duty to go to the International Court of Justice or to go to arbitration, the international law that is applicable to it becomes different in nature. One may call this law justiciable or arbitrable international law. It is very much superior in quality to the auto-interpretation type of international law.

Charter of the United Nations. Gradual Extension of the Compulsory Jurisdiction of the International Court of Justice (discussion), International Law Association, REPORT OF THE FIFTY-FIAST CONFERENCE 23, 44 (1964).

${ }^{35}$ Hudson, The Twenty-Sixth Year of the World Court, 42 AJIL 16 (1948).

169 AJIL 855 (1975). 
that applicable to fish or minerals in the high seas. The submarine sunk and was abandoned. Whoever found it thereafter was entitled to it.

The fact that dissimulation was used makes no difference because the action was legitimate and the dissimulation was used to cover up not the taking but a failure in lifting the remains of the sub. I believe the United States action was highly laudatory.

I see no questions being raised regarding the recovery of old vessels, sunken two or three hundred years ago, and their treasures. In those cases secrecy is used to keep away many others who would also like to search. May not this have been a consideration also speaking in favor of the position taken by the U.S. Government? Americans certainly bend over backwards in criticizing themselves.

José Thomaz Nabuco Rio de Janeiro 